\title{
Corporate social responsibility reporting within the Malaysian oil and gas industry: A questionable publicity stunt
}

\author{
Dayana Mastura Baharudin (D), Nik Hadiyan Nik Azman
}

School of Management,

Universiti Sains Malaysia

11800 USM Penang, Malaysia

\section{open 2 access (cc) dol}

\section{Article history:}

Received: August 27, 2018

1st Revision: December 12, 2018

Accepted: April 05, 2019

\section{JEL classification:}

M14

DOI:

10.14254/jems.2019.4-1.3

\begin{abstract}
This paper aims to challenge those involved in the CSR industry, non-governmental organizations (NGO) workers, CSR professionals and CSR consumers to question the real intentions by companies in their stance to move with the current trends and contribute towards a more sustainable and socially just society via their CSR activities. This paper used critically reviewed articles by using quantitative content analysis to analyse the High-Fit and Low-Fit CSR activities published within the Annual Reports, CSR Reports and company websites on firm performance over 5 years across the 30 oil and gas companies of Bursa Malaysia. This study finds that oil and gas companies should standardize their CSR reports based on the high-fit and low-fit CSR activities. By doing so, companies would be able to improve their reputation within the global community. This study could assist managers in oil and gas companies to review their CSR activities that indirectly give impacts towards social, economic and the environment.
\end{abstract}

Keywords: Corporate Social Responsibility (CSR), Environment, Social and Governance (ESG), Corporate Reputation (CR), sustainability.

\section{Introduction}

Fombrun (1996) trusted that the idea of corporate reputation (CR) which could risk corporations going into disrepute had been a noteworthy worry of specialists since the 1950s, in which there is an accord among researchers and experts alike that how the public recognize an organization will ultimately impact its corporate achievement in the future. Corporate reputation (CR) in the context of marketing disciplines illustrated the 'corporate associations that individuals establish with the company name' which is claimed by Fombrun et al (2000). This is supported by Davies et al (2003) which views corporate reputation as a force that can attract customers and is 
further validated by Bontis et al (2007) which stated that corporate reputation encourages loyalty among patrons alike. Lin et al (2003) has further agreed on the importance of corporate reputation which influences the selling-buying processes.

In the context of investors, Srivastava et al. (1997) contended that corporate reputation is an important criterion as present or potential shareholders see an organization with great status as a less hazardous venture than an organization with equal economic success but with notorious standing. The concept of Corporate Social Responsibility (CSR) has been trending for quite some time now despite the absence of a fixed definition. The European Commission (2000) has defined CSR as a concept whereby companies integrate social and environmental concerns in their business operations and in their interaction with their stakeholders on a voluntary basis.

Alternatively, the World Business Council on Sustainable Development (2000) has defined CSR as the commitment of business to contribute to sustainable economic development, working with employees, their families, the local community and society at large to improve their quality of life. The corporate reporting trends have changed over the last few decades in the view of globalization as business have become more conscious of their responsibilities other than the ultimate chase of profit and the traditional money-making mindset. Within the corporate world there seems to be a view that CSR may increase the chances of greater business opportunities over a long term period. Furthermore, there has been a growing competition amongst firms in CSR related activities together with the increased production of glossy reports coined as Sustainability report, Corporate Citizenship report and CSR report which are all part of a scheme on image building and public relations antics to win the hearts and minds of stakeholders worldwide.

The real intention behind the CSR publicity stunts remains a questionable issue despite the fact that the current corporate community are embracing CSR as a new form of modern corporate governance, in which in the absence would reflect a negative stance on the organization as a whole. What the world need is for the CSR activities to be a genuine co-operation between the organisation and society and not just as a corporate greenwashing tactic. Greenwashing can be described as when an organisation spends extensive time and money to be a green organisation through advertising and marketing but do not implementing the green business practices that minimizes the environmental impact. Therefore, the objectives of this study are to determine if the high-fit CSR (conducting CSR activities which relate closely to the core activity or core competencies of the organisation) or low-fit CSR (conducting CSR activities of an organisation do not relate to the core capabilities of an organisation) have an impact on firm performance. Second, to determine if the nine majors CSR practices moderates the relationship between the high-fit CSR or low-fit CSR activities and firm performance.

\section{Literature review}

In many jurisdictions, CSR is not governed by the Companies Acts or Codes of Corporate Governance as it is a form of voluntary best practice driven by the idea that business reputation and social awareness that determine business success globally. This is supported by Blowfield and Frynas (2005) which states that CSR is portrayed as the alternative to the government and acts as voluntary mechanisms to regulate business behaviour. Doane (2005) further supports this idea and argues that CSR events are largely anecdotal, which results in being highly questionable as CSR is purely voluntary, lies within the framework of markets, and requires market-based incentives for companies to invest in such programs. Over the last few decades, researchers have paid considerable attention to CSR. Therefore, it has become a prominent concept in management literatures (see; de Bakker, Groenewegen \& den Hond, 2005; Dobers, 2009; Nejati \& Ghasemi, 2012). Despite the large body of literature on CSR, there is still no unified and precise definition on CSR (Scherer \& Palazzo, 2007; Wood, 2010).

Thus, CSR does not mean the same thing to everybody (Van Marrewijk, 2003). Regardless of the lack of clear definition, all contending definitions of CSR agree on one issue, which is that firms must meet the expectations of society when planning their environmental management strategies (Gossling \& Vocht, 2007).

Swanson (1995) recommended that there are three key reasons for CSR performed by companies which are, the utilitarian point of view (a tool to assist in the accomplishment of operational goals), second, the negative obligation approach (impulse to receive socially capable activities to keep stakeholders happy) and third the positive obligation approach (companies are self-motivated and do not succumb to social demands). CSR is a tool used by many sinking and dying companies to revive or enhance their public appearance and to charm their clients and the general public. It is contradictory to see companies worldwide which provide deprived working conditions or inferior customer service use CSR to shield the truth and display social contribution and commitments to the general public intensified by social media. Examples of image polishing 
activities include donating a one-off sum of money and publicity stunt in the form of cleaning a beach for a day. Organisations seems to get the wrong concept of CSR in which they ultimately select certain external organisations which consists of charities, or marathons by giving large sums of monetary donation instead of looking into their own organisation to improve the work-lifebalance or employees minimum wage which might be a main source of dissatisfaction and concern to the organisation.

An excellent example would be of Starbucks, a coffee company which has a community store set-up to train community members in the neighborhood they serve in and also working directly with farmers around the world to produce the right coffee beans using environmentally friendly methods of farming. This shows a commitment of reinvesting back into the community whilst helping the company prosper at the same time. Another exemplary company would be The Body Shop, a British cosmetics and beauty chain which promotes the slogan of ' $100 \%$ vegetarian' and 'Against Animal Testing', which packages its products using renewable and recycled materials. The Body Shop also established factories in impoverished areas to take advantage of fresh and natural raw materials for their beauty products and at the same time assist the locals to have a betterquality livelihood in the name of the Community Trade Program.

In terms of oil and gas companies, worldwide CSR activities identifying with the oil and gas industry have risen lately. Most striking among these are the "Voluntary Principles on Security and Human Rights" (Voluntary Principles, 2010) in which the oil and gas industry focuses on human rights measures for their security tasks, and the "Extractive Industries Transparency Initiative" (Extractive Industries Transparency Initiative, 2010), in which organizations consent to deliberate reveal their monetary instalments to national governments as part of the transparency initiative. Moreover, various companies, law offices and management consultancies have developed to prompt the oil and gas industry on CSR concerns. Among these is the "Business for Social Responsibility", which works in various corporate segments, and has been engaged with various prominent activities of the oil and gas industry (Business for Social Responsibility, 2010).

\section{High-fit and Low-Fit CSR activities}

In terms of CSR activities, there are activities which are considered to be of a high-fit CSR activity which means conducting CSR activities which relate closely to the core activity or core competencies of the organisation. On the contrary there are also low-fit CSR activities in which CSR activities of an organisation do not relate to the core capabilities of an organisation. Generally, when the company's reputation is poor or tainted, conducting a high-fit CSR would only raise suspicion and disbelief within the global community.

Similarly, Sen and Bhattacharya (2001) suggested that consumers evaluate the company in a more favorable way when CSR activities are relevant to the company's existing product. It is obviously contradictory when Chevron, being an oil company promotes the importance to save energy and to drive a hybrid car as advertised extensively on billboards and the television. It is just as incongruous as McDonald's helping children while at the same time damage public health. Another oil and gas company, Baker Hughes has stirred controversy over pink fracking drill bits to reflect that despite being a major producer of fracking drill bits, they are also sensitive towards breast cancer. Baker Hughes worked with a charitable organisation, Susan G Komen for the Cure and paid USD 100,000 for the right to produce and sell the pink fracking drill bits to their clients.

This is shows that they are very concerned with finding a cure for breast cancer. On contrary fracking is an increasingly controversial process which gets oil and natural gas out of the hard-toaccess areas trapped in tiny pockets of rock. The fracking process also requires fluid of toxic substances such as benzene injected to break up the rock formations and release the hydrocarbon. The toxic fluids may seep into the underground layer of water-bearing permeable rock or gravel, sand or silt and ultimately contaminate groundwater which can be one of the sources for cancer. As the use of CSR is abused and is used mainly to serve an organisation's best interest foremost, and we now look further to the proposed conceptual framework below to understand the true reasons of CSR activities conducted by organisations worldwide.

$\mathrm{BP}$ was among the recognized leaders in sustainability reporting. A long-time "A+" reporter against the Global Reporting Initiative (GRI), BP has been listed by the Dow Jones Sustainability Index, FTSE4Good Index, has won numerous sustainability-related awards around the globe and regularly topped sustainability assessments, such as the Tomorrow's Value Rating. In short, BP has been a long-standing leader in the development of the "nuts and bolts" for a strong sustainability program (Cort, 2010). Although BP has a good image worldwide, unfortunately it has downside also. One of its pitfalls is regarding on the Deepwater Horizon incident. This accident happened in the Gulf of Mexico. BP was trying to save cost in terms of health and safety which resulted in a blowout that destroyed the economic, social and environmental livelihood of the people living on 
the Gulf of Mexico. This highlights the gap between messaging, perception and reality for the CSR industry.

CSR professionals ought to make some necessary inquiries in light of these clashing outcomes, for example, could a decent CSR expert can have such a unacceptable mistake agreeing to a key disaster of CSR, that authorities ought to be the main judge of duties related to the environmental and social problems, and should organizations answer to the anticipations of the authorities? Second, can culture (or financial specialists) trust the material contained within the published sustainability reports - for BP, the oil and gas industry, or some other organization? Third, did we (the CSR examiners and specialists) misunderstood and move toward becoming influenced by the cover up effect of the corporate sustainability reports templates and formats? Without solving these issues and come out with real genuine efforts, we can expect that CSR and sustainability reports will become increasingly about public relations and not for making investment or ethical decisions (Cort, 2010).

\section{Nine types of Corporate Social Responsibility (CSR) practices}

While trying to be internationally observed as socially mindful, associations lead exercises which run from corporate generosity, cause-related showcasing, supporting honors, sets of principles, social and ecological detailing, partner commitment, network speculation, ecoeffectiveness and putting resources into social centered organizations. The issue with corporate philanthropy is that it appears like a public relations practice due to the act of giving donation to charities in which organisations have further increased the donation amount to combat criticism such as the BP's sponsorship of the National Portrait Award. Cause-related marketing on the contrary has a different agenda in which Tesco's computer for schools programme which reflects a win-win situation where the schools will receive the computer aid and Tesco would be able to use the school's logo to appeal to the general public when marketing their goods to demonstrate their compassion. Sponsoring awards can be described through awards schemes, where companies position themselves as experts on an issue and leaders of CSR simply by making a large donation such as the Reebok Human Rights Awards. Codes of conduct as a type of CSR activity would be precise statements of company's values and standards of corporate behaviour, in which has received criticism as these codes are monitored by external verifiers which are the large accounting firms.

A type of CSR activity which is the publication of the social and environmental reports have been criticized for lacking common benchmarks, includes discretionary content of the company concerned, contains non-verifiable information which is not suited for stakeholders use and guidance. Stakeholder engagement as a form of CSR activity has received much disapproval as the mechanisms through which the stakeholders are engaged are entirely at the company's judgement. Community investment takes form of where organisations develop community projects in their locality to give back to the community that they operate in. This creates a comfortable atmosphere in the neighbourhood but creates anxiety when these companies take on these private functions in the public vicinities. Eco-efficiency related CSR measures which are contradictory to oil companies might be in the form of solar panels installed on the roofs of the petrol station and the pledge to reduce carbon emissions of its operations while still dedicated to a continual increase in the oil and gas drilling, exploration and production which are harmful to the environment.

\section{Firm performance}

Performance measurement can be refer to the process of measuring the action's efficiency and effectiveness" (Neely, Gregory \& Platts, 1995). In the current business management, performance measurement is in a more critical role compared to quantification and accounting" (Koufopoulos, Zoumbos \& Argyropoulou, 2008). Performance measurement is critical for effective management of any firm (Demirbag, Tatoglu, Tekinus \& Zaim, 2006). The process improvement is not possible without measuring the outcomes. Hence, organizational performance improvement requires measurements to identify the level to which the use of organizational resources impact business performance (Gadenne \& Sharma, 2002; Madu, Aheto, Kuei \& Winokur, 1996).

The company's prosperity is fundamentally clarified by its operation over a specific interval. Prior research has increased the attempts to identify the measurement of operational success as a significance. Finding an estimation for the successful operation of the firm empowers the contrast of operational success over various eras. Measurement of performance can offer significant invaluable information to allow management's monitoring of performance, report progress, improve motivation and communication and pinpoint problems" (Waggoner, Neely \& Kennerley, 1999). This study measure firm performance based on Return on Equity (ROE). Return on equity (ROE) is an accounting-based performance measures to evaluate the firm's performance, which are computed as the ratio of net profit to average total equity" (El-Sayed Ebaid, 2009). 


\section{Conceptual framework, hypothesis development and theoretical framework}

Figure 1: Conceptual framework

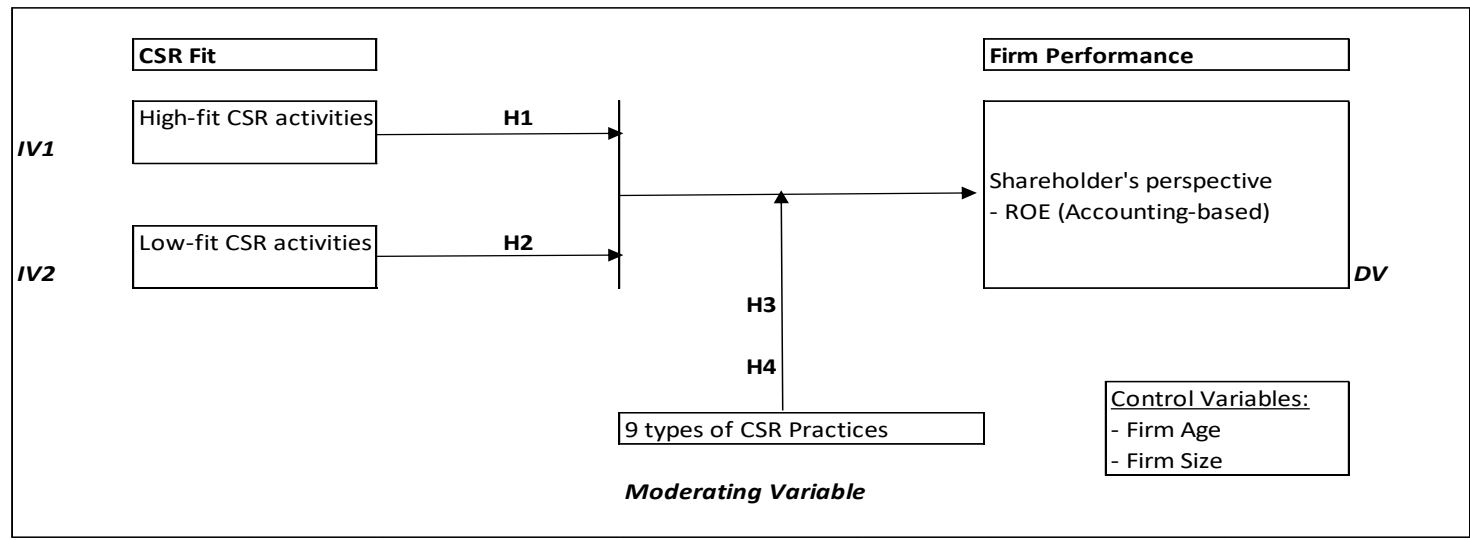

H1: High-fit CSR activities has a significant role towards increasing firm performance in terms of shareholders perspective using ROE as a proxy.

H2: Low-fit CSR activities has a significant role towards increasing firm performance in terms of shareholders perspective using ROE as a proxy.

H3: The nine types of CSR practices moderate the relationship between the high-fit CSR activities and firm performance in terms of shareholders' perspective using ROE as a proxy.

H4: The nine types of CSR practices moderate the relationship between the low-fit CSR activities and firm performance in terms of shareholders' perspective using ROE as a proxy.

\section{Methodology}

Measurement of the independent variables: Distinction between means-level and endslevel CSR fit

"A first observation that emerged from the data was that it is important to distinguish between means-level and end-level CSR fit. In the case of means-level fit, the relationship between the CSR activity and the organization's core business is found in the means the organization uses for the CSR activity. In the case of ends-level fit, the relationship is found in the ends the organization wants to achieve with the activity. This leads to a 2 by 2 matrix of CSR fit, in which fit can be determined in two complementary ways (see Table 1). The following examples from the corpus may illustrate the distinction between the two types of fit. Examples of CSR activities with both means-level and ends-level fit (cell A, $n=69$ ) are (1) the dairy firm's decision to reduce the amount of sugar, fat and salt in products, to enhance consumers' health, and (2) the bank's policy to provide microfinancing to beginning entrepreneurs, to help them get started. Examples of CSR activities with a means-level fit but without an ends-level fit (cell B, n = 13) are (1) the printing house's initiative to give underprivileged youngsters the opportunity to make their own magazine, to give them the chance to extend their horizons, and (2) the consumer goods and healthcare instruments firm's policy to encourage and support volunteering work of its employees, to give something back to society. Examples of CSR activities with an ends-level fit but without a meanslevel fit (cell $C, n=13$ ) are (1) the printing house's financial contribution to cultural events in its immediate surroundings, to further the region where it is located, and (2) the bank's initiative to collect and recycle used cell phones of employees, to promote the sustainable use of resources. Examples of CSR activities with neither means-level nor ends-level fit (cell D, n = 7) are (1) the mail delivery firm's initiative to produce and sell a cookbook, to collect money for children in developing countries for offering meals at school, and (2) the dairy firm's contribution to ergonomic school furniture in a developing country, to enhance the educational situation in this country" (De Jong \& Van der Meer, 2015). 
Table 1: Means-level and ends-level CSR fit

\begin{tabular}{lcc} 
& Ends Level Fit & No Ends Level Fit \\
\hline Means-Level Fit & $\mathrm{A}(\mathrm{n}=69)$ & $\mathrm{B}(\mathrm{n}=13)$ \\
No Means-Level Fit & $\mathrm{C}(\mathrm{n}=13)$ & $\mathrm{D}(\mathrm{n}=7)$ \\
\hline
\end{tabular}

Source: De Jong \& Van der Meer (2015)

We will extend this measurement via quantitative content analysis to determine the classification of high-fit and low fit CSR activities as follows:

1. Means-level fit and Ends-level fit $=10$ points $=$ High- fit CSR

2. Ends-level fit only $=5$ points $=$ Low -fit CSR

3. Means-level fit only $=5$ points $=$ Low -fit CSR

4. None of either Means-level fit or Ends-level fit $=0$ points $=$ Low-fit CSR

\section{Measurement of the moderating variable: Content analysis procedure}

Zahid and Ghazali (2015) utilized the content analysis of REITs and property companies' annual reports published during 2011, 2012 and 2013 to determine the extent or level of corporate sustainability disclosures (environmental sustainability, social sustainability and economic sustainability). Content analysis is the most popular and widely using method in research on accounting disclosures (Boesso and Kumar, 2007). Content analysis may have both qualitative and quantitative measurements. Quantitative content analysis considered to be the more reliable (Zahid and Ghazali, 2015; Day and Woodward, 2009).

\section{Measurement of the dependent variable}

This research will employ the Return on Equity (ROE) which will look at the firm performance based on the Shareholders' perspective. ROE is measured by Profit after tax divided by the total equity shares in issue Al Manaseer et al., (2012),Obiyo and Lenee (2011), Rouf (2011), Swamy (2011), Ibrahim and AbdulSamad (2011),Yasser, Entebang and Mansor (2011), Dar, Naseem, Rehman and Niazi (2011), Chaghadari (2011), Heenetigala and Armstrong (2011).

\section{Proposed models for empirical testing}

Against this background and in line with the objectives of this study, the following models are proposed for future empirical testing:

Research Objective 1, Research Question1 \& Hypothesis 1:

$$
F P=\beta 0+\beta 1 H F C S R+\beta 2 A G E+\beta 3 S I Z E+\varepsilon i t
$$

Research Objective 1, Research Question 1 \& Hypothesis 2:

$$
F P=\beta 0+\beta 1 L F C S R+\beta 2 A G E+\beta 3 S I Z E+\varepsilon i t
$$

Research Objective 2, Research Question 2 \& Hypothesis 3:

$$
F P=\beta 0+\beta 1 H F C S R+(\beta 1 H F C S R * M A J C S R)+\beta 3 A G E+\beta 4 S I Z E+\varepsilon i t
$$

Research Objective 2, Research Question 2 \& Hypothesis 4:

$$
F P=\beta 0+\beta 1 L F C S R+(\beta 1 L F C S R * M A J C S R)+\beta 3 A G E+\beta 4 S I Z E+\varepsilon i t
$$

Where:

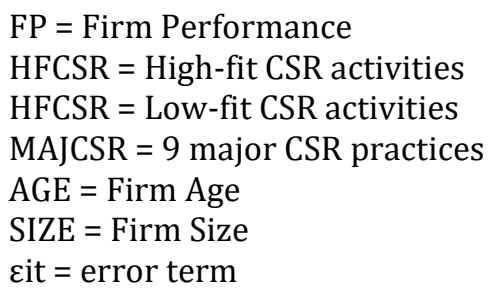

Prior research on CSR have only focused on the normative and instrumental aspects of the stakeholder theory. The normative and instrumental approach of stakeholder theory focuses on the moral obligations of a firm and the instrumental benefits of these moral obligations. Majority of the prior research ignore the descriptive approach of the stakeholder theory in which the descriptive 
approach describes the guidance steps for firms to implement CSR activities which are of high-fit in nature. This study will determine if companies are practicing high-fit or low-fit CSR activities in which proper high-fit implementation of CSR will need to take place going forward to ensure ongoing firm performance. The proper high-fit implementation of CSR will reflect the descriptive approach to the stakeholder theory. In term of methodology, this study will introduce a moderator variable of the nine types of CSR practices in which prior research have not considered the moderating effects of different CSR practices that could enhance firm performance. This study will also extend prior research methodology on measuring the means-level fit and the ends-level fit towards an extensive classification by awarding points for each company. Practically, this study aims to produce a CSR index to be used as guidance indicators for the Malaysian public listed companies on Bursa Malaysia in terms of high-fit CSR, low-fit CSR, means-level fit and ends-level fit CSR activities.

\section{Conclusion and a way forward}

CSR will just improve an organization's status or ability to obtain funding if the general population is persuaded that they truly are positively affecting society. The general population which is distrustful at present may have been tricked for so long, as organizations keep on polluting, benefit financially from wars, misuse defenceless employees and increase the space between the rich and poor until to the point that CSR is deemed as scam. Numerous organizations have broadly dropped their CSR duties when they suffer from shortage of money, for example, in Littlewoods hauled out of the "Ethical Trading Initiative" and split up its ethical trading initiative group when it encountered money shortage issues in which their organisations needed to be sold to L.W Speculations Ltd in November 2002. For CSR to be successful in any country there must be an establishment of vigorous guidelines, authorization and penalties for lack of compliance. In many emerging economies, the drive to administer and authorize CSR practices are not there. Over the long haul, companies ought to gain by creating viable CSR options over a period of time into the future, for example, putting resources into Fairtrade, to move the society into being a more selfsustainable society with lessening the corporate control which in turn could reduce the genuine CSR activities.

\section{Appendix A. Supplementary material}

Supplementary data associated with this article can be found, in the online version, at https://doi.org/10.14254/jems.2019.4-1.3

\section{Funding}

The authors received no direct funding for this research.

\section{Citation information}

Baharudin, D. M., \& Nik Azman, N. H. (2019). Corporate social responsibility reporting within the Malaysian oil and gas industry: A questionable publicity stunt. Economics, Management and Sustainability, 4(1), 29-36. doi:10.14254/jems.2019.4-1.3

\section{References}

Al Hinai, M. (2014). CSR works when done properly and not as a publicity stunt. Retrieved from http://www.thenational.ae.

Allen, F. (2012). The Gulf Spill BP Still Doesn't Get it. Retrieved from http://www.forbes.com/sites/csr/

Corporate Watch Report. (2006). What's wrong with Corporate Social Responsibility?.

European Commission Green Paper. (2000). Promoting a European Framework for Corporate Social Responsibility. Retrieved from http://europa.eu.int/comm/employment_social/soc-dial/csr/

Ferguson, M.A. (2010). Why CSR Can't Help BP Now. Retrieved from http://www.forbes.com

Fortune Global 500. (2014). Retrieved from http://fortune.com/global500/royal-dutch-shell-2/

Gardner, K., Ahmed, Z., Bashir, F., \& Rana, M. (2012). Elusive partnerships: Gas extraction and CSR in Bangladesh. Resources Policy, 37(2), 168-174. 
Global Investment Watch. (2008). Chevron: Burning Oil for the Environment?

Hilson, G. (2012). Corporate Social Responsibility in the extractive industries: Experiences from developing countries. Resources Policy, 37(2), 131-137.

Kaye, L. (2012). Chevron Ramps Up Anti-AIDS Agenda: CSR or PR? Retrieved from www.triplepundit.com

Krishnamurthy, V. (2014). Mandatory Social and Financial Reporting: Coming Soon to the European Union. Retrieved from www.csrandthelaw.com

Maden, C., Arıkan, E., Telci, E. E., \& Kantur, D. (2012). Linking corporate social responsibility to corporate reputation: a study on understanding behavioral consequences. Procedia-Social and Behavioral Sciences, 58, 655-664.

Maniruzzaman, A. F. M. (2011). Creeping legitimacy of corporate social responsibility. Amicus Curiae, 2011(85), 1-2.

McGee, S. (2014). How breast cancer research benefits from fracking and other abominations. Retrieved from www.theguardian.com

Muralidharan, S., Dillistone, K., \& Shin, J. H. (2011). The Gulf Coast oil spill: Extending the theory of image restoration discourse to the realm of social media and beyond petroleum. Public Relations Review, 37(3), 226-232.

Saeidi, S. P., Sofian, S., Saeidi, P., Saeidi, S. P., \& Saaeidi, S. A. (2015). How does corporate social responsibility contribute to firm financial performance? The mediating role of competitive advantage, reputation, and customer satisfaction. Journal of business research, 68(2), 341350.

Shell. (2015). Sustainability reporting and performance data. Retrieved from https://www.shell.com/global/environment-society/reporting/our-approach.html

Slack, K. (2012). Mission impossible?: Adopting a CSR-based business model for extractive industries in developing countries. Resources Policy, 37(2), 179-184.

Swanson, D. L. (1995). Addressing a theoretical problem by reorienting the corporate social performance model. Academy of management review, 20(1), 43-64.

World Business Council on Sustainable Development. (Jan 2000). Corporate Social Responsibility: Making Good Business Sense. Retrieved from www.wbcsd.org

Yoon, Y., Gürhan-Canli, Z., \& Schwarz, N. (2006). The effect of corporate social responsibility (CSR) activities on companies with bad reputations. Journal of consumer psychology, 16(4), 377390.

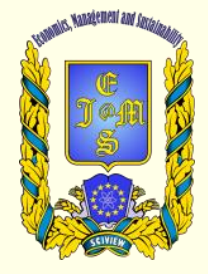

(C) 2016-2019, Economics, Management and Sustainability. All rights reserved.

This open access article is distributed under a Creative Commons Attribution (CC-BY) 4.0 license.

You are free to:

Share - copy and redistribute the material in any medium or format Adapt - remix, transform, and build upon the material for any

purpose, even commercially.

The licensor cannot revoke these freedoms as long as you follow the license terms.

Under the following terms:

Attribution - You must give appropriate credit, provide a link to the license, and indicate if changes were made.

You may do so in any reasonable manner, but not in any way that suggests the licensor endorses you or your use.

No additional restrictions

You may not apply legal terms or technological measures that legally restrict others from doing anything the license permits.

Economics, Management and Sustainability (ISSN: 2520-6303) is published by Scientific Publishing House "CSR",

Poland, EU and Scientific Publishing House "SciView", Poland

Publishing with JEMS ensures:

- Immediate, universal access to your article on publication

- High visibility and discoverability via the JEMS website

- Rapid publication

- Guaranteed legacy preservation of your article

- Discounts and waivers for authors in developing regions

Submit your manuscript to a JEMS at http://jems.sciview.net or submit.jems@sciview.net

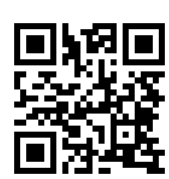

